\title{
Effects of international marketing environments on entrepreneurship development
}

\author{
M. E. Agwu* (D) and H. N. Onwuegbuzie
}

\author{
* Correspondence: \\ edwinagwu@yahoo.co.uk; \\ edwinagwu@lbs.edu.ng \\ Faculty of Strategy and \\ Entrepreneurship Lagos Business \\ School, Pan-Atlantic University, Km \\ 22, Lekki-Epe Expressway, Ajah, \\ Lekki, Lagos State, Nigeria
}

\begin{abstract}
Entrepreneurs all over the world seek ways of introducing their products to international markets; unfortunately, the international marketing environment poses a lot of opportunities and threats to foreign entrants. The cultural, political, and technological environments act as determinant factors in entrepreneurial success in global markets. This study aims to unravel the effects of these international marketing environments on entrepreneurial developments. The study being descriptive and historical relied heavily on secondary sources of information. Analysis revealed that the PESTEL and other human factors have significant impacts on business transactions. Furthermore, the political systems and governmental regulations on business dealings have a lot to do with entrepreneurial success in the international arenas. The study recommends the establishment of a supportive governmental framework to serve as a platform for the willing entrepreneurs to succeed in the international markets.
\end{abstract}

Keywords: Entrepreneurship, International market, Comparative advantage, Barriers, Government

\section{Background to the study}

The international market serves as an avenue for creative entrepreneurs to earn foreign income outside their country of existence. According to Kotler (2007), "international marketing" refers to exchanges across national boundaries for the satisfaction of human needs and wants and the extent of a firm's involvement abroad is a function of its commitment to the pursuit of foreign markets. The author stressed that the demands are tough and the stakes are high. International business entrepreneurs are not only sensitive to different marketing environments internationally but also balancing marketing moves worldwide to seek optimum results for their businesses Davis et al. (2017). However, the activities in the international business environment make it highly competitive for many who want to venture in the international arena with their products due to dynamic nature of environment (Biraglia and Kadile 2017). Lim et al. (2016) stressed that environmental factors are unpredictable and in most times form the basis for decision for local entrepreneurs to break into new markets. There are many ways to break into new untested markets which include exporting, foreign direct investment, joint venture, and international partnerships; all these options seem to tie

(c) The Author(s). 2018 Open Access This article is distributed under the terms of the Creative Commons Attribution 4.0 International License (http://creativecommons.org/licenses/by/4.0/), which permits unrestricted use, distribution, and reproduction in any medium, provided you give appropriate credit to the original author(s) and the source, provide a link to the Creative Commons license, and indicate if changes were made. 
their feasibility round what is obtainable in the market to break into (Zwan et al. 2016). For example, factors like technological change and cultural and international governmental laws are difficult to predict to get a business to be stable in a new international arena. In retrospect, the effects of international marketing environment to the entrepreneurs in the developing economies cannot be overemphasized as the effects of international environment have not gotten so much reference and research. Mahmoud and Muharam (2014) argued that a lot of factors considered to be important elements that account for the growth and remarkable performance of the entrepreneurial ventures in Nigeria are not directed towards international environmental factors. Ayoade and Agwu (2016) assert that the effects of international marketing environment on business entrepreneurs are not completely clear. This is because the businesses of today are operating in an era in which the greater part of social life is determined by global processes, in which national cultures, national economies, and national borders are dissolving. Central to this perception according to Cardon and Kirk (2015) is the notion of a rapid and recent economic globalization in which modern entrepreneurs have to deal with customers who are changing with channels of distribution that are also changing. They also have to deal with the technological advances that are changing the nature of their products and services and requiring them to operate imaginatively and effectively in the emerging markets. The basic nature of marketing does not change from domestic to international marketing, but marketing outside national boundaries poses special problems, such as dealing with multiple environments, managing operations in distant markets, optimizing businesses in more than one country, and dealing with foreign nationals (Lim et al. 2016). Venturing into international marketing therefore, unlike domestic marketing, requires operating simultaneously in more than one kind of environment, coordinating one's business operations, and using the experience gained in one country for making decisions in another country (Biraglia and Kadile 2017).

Based on the above, this study sets out to examine the effects of international marketing environmental challenges and ascertain how prospective entrants can meander the muddy waters as well as ride the high waves created by these challenges in order to create opportunities to move their organizations forward and generate more revenues.

\section{Literature review}

Governments all over the world support cross-border entrepreneurship and in particular exports with the aim to increase national wealth and to improve international competitiveness of the national economy (OECD 1997; Taiwo et al. 2016). Cross-border entrepreneurship has become a more widespread phenomenon in the past decades. Traditionally, multinational enterprises were mainly responsible for flows of international trade and foreign direct investments, which are the prime driving forces of globalization. However, the recent increase in international trade and investment flows stems mainly from firms that used to focus primarily on domestic markets and not from firms that are already global players (Muller 2004, Lim et al. (2016). One feature of today's globalizing economy is that a growing number of firms are undertaking international activities and these include not only large firms, but also, and increasingly, small and new ventures, through the use of information technology (Agwu 2018). Another feature of the current globalizing economy, according to Onwuegbuzie and Agwu (2018), is that firms, even small and new ventures, are internationalizing at a faster pace. Firms that were traditionally mainly domestic are 
internationalizing incrementally, starting with activities that involve low levels of risk and low levels of commitment of resources, such as indirect export (i.e., export with the help of an intermediating firm), before making a more substantial commitment in foreign markets through producing abroad (Johanson and Vahlne 1977, 1990). Nigerian entrepreneurs have been adjudged to be creative in their endeavors which is a major requirement for business sustainability, and the quest to expand into larger markets to increase market size and opportunities for their product is no exception (Mahmoud and Muharam 2014). Being a local entrepreneur gives one an insight to what is obtainable in one's immediate environment, but entering foreign markets is highly tasking and challenging because many requirements and demands expected from the entrepreneur in the country of operation must be met. The assistance of the home government comes to play in this regard as most of the huddles can be smoothened through multi-layer assistances.

\section{Meaning of entrepreneurship}

The word "entrepreneurship" derives from the French words entre, meaning "between," and prendre, meaning "to take." The word was originally used to describe people who "take on the risk" between buyers and sellers or who "undertake" a task such as starting a new venture (Barringer and Ireland 2005, p. 5). It is also important to distinguish between inventors and entrepreneurs as they differ from each other. An inventor creates something new. An entrepreneur assembles and then integrates all the resources needed, and these include the money, the people, the business model, the strategy, and the risk-bearing ability to transform the invention into a viable business (Taiwo and Agwu 2016). Therefore, "entrepreneurship" is the process by which individuals pursue opportunities without regard to resources they currently control. The essence of entrepreneurial behavior is to identify opportunities and put useful ideas into practice (Agwu et al. 2017). The tasks called for by this behavior can be accomplished by either an individual or a group and typically require creativity, drive, and a willingness to take risks (Barringer and Ireland 2005, p. 5). Entrepreneurship has long been described by researchers and practitioners with terms such as new, innovative, flexible, dynamic, creative, and risk-taking. Several authors and practitioners have stressed that identifying and pursuing opportunities is an important part of entrepreneurship. Others view entrepreneurship as involving the creation of values and the process of starting or growing a new profit-making business, the process of providing a new product or service, and the intentional creation of value through organization by an individual contributor or a small group of partners Biraglia and Kadile 2017; Mahmoud and Muharam 2014; Van der Zwan et al. 2010). Coulter (2003, p. 4) viewed entrepreneurship as "the process of creating something different with value by devoting the necessary time and efforts, assuming the accompanying financial, psychological, and social risks, and receiving the resulting rewards of monetary and personal satisfaction."

\section{The entrepreneur}

An entrepreneur is the one who creates a new business in the face of risk and uncertainty for the purpose of achieving profit and growth by identifying significant opportunities and assembling the necessary resources to capitalize on them (Zwan et al. 2016). The three primary reasons why people become entrepreneurs and start their own firms are: 
- To be their own boss-either they have had a long-time ambition to own their own firm or they have become frustrated working in traditional jobs.

- Pursue their own ideas-some people are naturally alert, and when they recognize ideas for new products or services, they have a desire to see those ideas realized.

- Realize financial rewards-this motivation is typically secondary to the first two and often fails to live up to its hype (Barringer and Ireland 2005).

Regardless of the motives for being an entrepreneur, it is the act of creating a business (i.e., perceiving an opportunity, assessing and risking resources to exploit the opportunity, managing the process of building a venture from an idea, and creating value) that makes it the entrepreneurial act (Mahmoud and Muharam 2014). It should have a new insight, the preparedness to be committed, and the readiness to take risks. Whereas most people think of entrepreneurial ventures as launching new businesses, it is usually considered to be an individual's activity. However, established firms also can behave entrepreneurially. Typically, established firms with an entrepreneurial emphasis are proactive, innovative, and risk-takers; however, the degree of entrepreneurship is dependent on the type of industry.

\section{Challenges of entrepreneurs in developing economies}

Research trends show that cross-border activities, such as exports, are very important means through which small and new ventures are able to create value, to generate growth, and to access new knowledge and technologies (Yeoh 2004). Nowadays, the internationalization of small and medium enterprises (SMEs) and new ventures is both expanding and accelerating, which is likely to further contribute to a greater number of economic actors pursuing foreign markets (Hessels 2007). The expansion and acceleration of cross-border entrepreneurship can be considered in the light of substantial changes that took place in the past decades and that resulted in a reduction of transaction costs for undertaking international businesses.

Ofili (2014) stressed that there are several challenges of potential entrepreneurs in developing economies and top on the list is the determinants of the conditions of entry into these new markets. This according to Zwan et al. (2016) is defined as the power of the established sellers in an industry to persistently raise prices above the competitive level without thereby deterring new firms to enter. And these are premised on:

- An absolute cost advantage for established firms, such as the control of production techniques through patents, imperfections in factor markets, which give them lower buying prices, and money market imperfections, which impose higher interest rates on potential entrants

- Circumstances favoring product differentiation through brand preferences and company reputation; and

- Significant economies of scale, for example, where the minimum efficient scale is relatively large to the industry as a whole, thus giving the optimum firm a significant share of the market.

Based on the above, it is evident that barriers to new entry are characteristics of oligopoly, and it is remarkable that most of the oligopolies in developing economies are 
expatriates. This does not mean that there is any conscious behavior on the part of the firms, expatriate or indigenous, to block or effectively impede new entry, but, where such circumstances have arisen, the industry remains the exclusive preserve of the established firms (Reuber et al. 2018). Where such firms are non-indigenous, the removal of entry barriers to indigenous enterprise requires special policy measures.

The second, perhaps the most important major obstacle to indigenous enterprise in manufacturing, is ignorance on the part of potential investors (Zwan et al. 2016). It has been observed that theories of underdevelopment related to a lack of entrepreneurial spirit are inapplicable to most developing economies. Most practitioners in developing economies appear to be actively seeking material rewards, and entrepreneurship as such is socially honored (Stephan and Stride 2015). Many entrepreneurs, according to Taiwo et al. (2016), are alert to profit opportunities and can find the necessary capital for industrial projects which seem to be within their capacity to exploit. The preponderance of entrepreneurial enterprises in sawmilling, grain milling, canning and preserving fruit and vegetables, and so on, conclusively points to the abundance of imitating entrepreneurs- "those who adopt a new economic practice after a local innovator has demonstrated it to be practical and profitable" in industries with simple technology and modest initial capital.

The third major pre-investment obstacle is the difficulty of access to productive resources such as capital, managerial and skilled manpower, and an adequate flow of raw materials. Even an adequate supply of funds may not ensure that the other factors are forthcoming in the short run (Van der Zwan et al. 2010). The potential indigenous entrepreneurs are not as fortunate as their foreign counterparts. Although not barred from international factor markets, the indigenous investors lack the knowledge and experience, which are the intangible assets of expatriate investors, to operate in such markets. These indigenous entrepreneurs have no locus standing; even in the domestic money market and where some of their raw materials are imported, they may find it more difficult to meander through the network of administrative controls; happily, some of these controls are now being relaxed in most developing economies. Related to the inaccessibility of factors is the absence of external economies which Taiwo and Agwu (2016) described as an obstacle inherent in the economic environments, for example, the long delays before the delivery of machinery and equipment, the difficulty of obtaining the right type of spare parts and supplies, and the difficulty of obtaining skilled service and repairs, all of which entrepreneurs in developed economies take for granted. And another aspect of this problem is the unwillingness of most indigenous entrepreneurs to pool their resources for a joint business venture (Mahmoud and Muharam 2014).

\section{International environmental forces}

The international environment is very important from the point of view of certain categories of businesses. It is particularly important for industries directly depending on imports or exports and import-competing industries. For example, a recession in foreign markets, or the adoption of protectionist policies by foreign nations, may create difficulties for industries depending on exports. On the other hand, a boom in the export market or a relaxation of the protectionist policies may help the export-oriented industries (Coulter et al. 2008). A liberalization of imports may help some industries 
which use imported items but may adversely affect import-competing industries. It has been observed that major international developments have their spread effects on domestic businesses. The last economic recession in the global world sent its shock waves to a number of other countries. Oil price hikes seriously affected a number of economies, and these hikes increased the cost of production and the prices of certain products. The high oil price has led to an increase in the demand for automobile models that economize fuel consumption. Therefore, a good understanding of export market enables a firm to develop a more profitable product mix and to consolidate its position in the domestic market. Many companies now plan production capacities and investment taking into account also the foreign markets. Export marketing facilitates the attainment of optimum capacity utilization; a company may be able to mitigate the effects of domestic recession by exporting. However, a company which depends on the export market to a considerable extent also faces the impact of adverse developments in foreign markets.

There are various international environmental forces that mitigate entrepreneurs seeking internationalization to their business. Some of these factors which include but not limited to political and legal factors, natural environmental factors, demographic factors, and physical and technological factors are explained below.

\section{Political and legal factors}

Political and government environments have close relationship with business strategy formulation because of competition. For example, the communist countries had a centrally planned economic system. In most developed countries such as the UK and USA, apart from those laws that control investment and related matters, there are a number of laws that regulate the conduct of businesses. These laws cover such matters as standards of products, packaging, promotion etc.; also, with a view of protecting consumer interests and local industries, regulations have become stronger (Lim et al. (2016). Regulations to protect the purity of the environment and preserve the ecological balance have assumed great importance in many countries. Some governments such as in the UK, USA, and Germany specify certain standards for the products (including packaging) to be marketed in the country and some even prohibit the marketing of certain products. In most developed nations, as stated above and others, promotional activities are subject to various types of controls (Allen 2003). Media advertising is not permitted in Libya, and several European countries restrain the use of children in commercial advertisements. In a number of countries, including in Europe and India, the advertisement of alcoholic liquor is prohibited. Advertisements, including packaging, of cigarettes must carry the statutory warning that "cigarette smoking is injurious to health." Similarly, advertisements of baby food must necessarily inform the potential buyer that breastfeeding is the best, Biraglia and Kadile (2017). In countries like Germany, product comparison advertisements and the use of superlatives like "best" or "excellent" in advertisements are not allowed in the USA. Many countries today such as the EU and USA have laws to regulate competition in the public interest. Elimination of unfair competition and dilution of monopoly power are the important objectives of these regulations (Davis et al. 2017). Changes are constant in various government policies such as the industrial policy, fiscal policy, and tariff policy; these changes often have profound impacts on businesses especially entrepreneurs; however, 
some policies create opportunities as well as threats. In other words, a development which brightens the prospects of some enterprises may pose a threat to some others; for example, the industrial policy liberalizations in Nigeria, particularly around the mid-1980s, opened up new opportunities and threats. They provided a lot of opportunities to a large number of enterprises to diversify and to make their product-mix better. But they have also given rise to serious threat to many existing products by way of increased competitions; many seller's markets have given way to buyer's markets (Ayoade and Agwu, 2016; Mahmoud and Muharam, 2014).

\section{Socio-cultural factor}

The socio-cultural fabric is an important environmental factor that must be analyzed while formulating business strategies (Feenstra and Hanson 2005). The cost of ignoring the customs, traditions, taboos, tastes and preferences, etc., of people could be very high. Lim et al. (2016) stressed that the buying and consumption habits of the people, their language, beliefs and values, customs and traditions, tastes and preferences, and education are all factors that affect business. For a business to be successful, its strategy should be the one that is appropriate in the socio-cultural environment. The marketing mix will have to be so designed as best to suit the environmental characteristics of the market. For instance, in Nigeria Nestle, a Swiss multinational company today boasts of more than 20 varieties of instant beverage products to satisfy different national tastes. Even when people of different cultures use the same basic products, the mode of consumption, conditions of use, purpose of use, or the perceptions of the product attributes may vary so much so that the product attributes method of presentation, positioning, or method of promoting the product may have to be varied to suit the characteristics of different markets. The differences in languages sometimes pose a serious problem, even necessitating a change in the brand name. Tallman and Li (1996) stressed that "Preett" was, perhaps, a good brand name in India, but it did not suit the overseas market, and hence, it was appropriate to adopt "Prestige" for the overseas markets. Chevrolet's brand name "Nova" in Spanish means "it doesn't go." In Japan, General Motors' "Body by Fisher" translates as "corpse by Fisher." In Japan, again, 3M’s slogan "sticks like crazy" translates as "sticks foolishly." In some languages, Pepsi-Cola's slogan "come alive" translates as "come out of the grave" (Prahalad and Mashelkar 2010). Similarly, the values and beliefs associated with color vary significantly between different cultures. For instance, blue, considered feminine and warm in Holland, is regarded as masculine and cold in Sweden. Green is a favorite color in the Muslim world, but in Malaysia, it is associated with illness. White indicates death and mourning in China and Korea, but in some countries, it expresses happiness and is the color of the wedding dress of the bride (Zwan et al. 2016). Social inertia and associated factors come in the way of the promotion of certain products, services, or ideas. There are such social stigmas in the marketing of family planning ideas, use of biogas for cooking, etc. In such circumstances, the success of marketing depends, to a very large extent, on the success in changing social attitudes or value systems. There are also a number of demographic factors, such as the age, sex composition of population, family size, habitat, and religion, which influence businesses, while dealing with the social environment. According to Rennie (1993), a business must also consider the social environments of 
the business which encompasses its social responsibility and the alertness or vigilance of the consumers and of society at large. The societal environment has assumed great importance in recent years. Today, however, business is being asked to take a responsibility for the quality of life in our society. The expectation is that businesses-in addition to its traditional accountability for economic performance and results-will concern itself with the health of the society that it will come up with the cures for the ills that currently beset the society and, indeed, must find ways of anticipating and preventing future problems in these areas (Shane 2003).

\section{Demographic factors}

Demographic factors such as size of the population, population growth rate, age composition, life expectancy, family size, spatial dispersal, occupational status, and employment pattern affect the demand for goods and services. Markets with growing populations and incomes are growth markets (Hamel and Prahalad 1994). A rapidly increasing population indicates a growing demand for many products. High population growth rate also indicates an enormous increase in labor supply. When the Western countries experienced the industrial revolution, they had the problem of labor supply because the population growth rate was comparatively low. Labor shortage and rising wages encouraged the growth of labor-saving technologies and automation. But most developing countries of today are experiencing population explosion and in some countries, a sort of labor surplus. The governments of developing countries, therefore, encourage labor-intensive methods of production. Capital-intensive methods, automation, and even rationalization are opposed by labor and many sociologists, politicians, and economists in these countries (McDougall and Oviatt 2000). The population growth rate, thus, is an important environmental factor which affects businesses. Cheap labor and growing markets have encouraged many multinational corporations to invest in developing countries. The occupational and spatial mobilities of population have implications for business. If labor is easily mobile between different occupations and regions, its supply will be relatively smooth, and this will affect the wage rate. If labor is highly heterogeneous in respect of language, caste and religion, ethnicity, etc., personnel management is likely to become a more complex task. The heterogeneous population with its varied tastes, preferences, beliefs, temperaments, etc., gives rise to differing demand patterns and calls for different marketing strategies (Greenaway et al. 2008).

\section{Natural environmental factors}

Geographical and ecological factors, such as natural resource endowments, weather and climatic conditions, topographical factors, locational aspects in the global context, and port facilities, are all relevant to businesses. Differences in geographical conditions between markets may sometimes call for changes in the marketing mix (Murnieks et al. 2016). Geographical and ecological factors also influence the location of certain industries. For example, industries with high material index tend to be located near the raw material sources. Climatic and weather conditions affect the location of certain industries like the cotton textile industry, and topographical factors may affect the demand pattern. For example, in hilly areas with a difficult terrain, jeeps may be in greater demand than cars. Ecological factors have recently assumed great importance. 
The depletion of natural resources, environmental pollution, and the disturbance of the ecological balance have caused great concern. Government policies aimed at the preservation of environmental purity and ecological balance, conservation of non-replenishable resources, etc., have resulted in additional responsibilities and problems for business, and some of these have the effect of increasing the cost of production and marketing. Externalities have become an important problem businesses have to contend with (Stephan and Stride (2015).

\section{Physical and technological factors}

Physical factors, such as geographical factors, weather, and climatic conditions, may call for modifications in the product, etc., to suit the environment because these environmental factors are uncontrollable. For example, Exxon Mobil adapted its gasoline formulations to suit the weather conditions prevailing in different markets. Business prospects depend also on the availability of certain physical facilities. Barringer and Ireland (2005) stressed that some products, such as some consumer durables, have certain use facility characteristics. The sale of television sets, for example, is limited by the extent of the coverage of the telecasting. Similarly, the demand for refrigerators and other electrical appliances is affected by the extent of electrification and the reliability of power supply. The demand for LPG gas stoves is affected by the rate of growth of gas connections. Technological factors sometimes pose problems, and a firm, which is unable to cope with the technological changes, may not survive. Further, the differing technological environment of different markets or countries may call for product modifications. For example, many appliances and instruments in the developed countries are designed for $110 \mathrm{~V}$ but this needs to be converted into $220 \mathrm{~V}$ in a country like Nigeria. Advances in the technologies of food processing and preservation, packaging etc., have facilitated product improvements and introduction of new products and have considerably improved the marketability of products (Greenaway et al. 2008). The television has added a new dimension to product promotion with the advent of LCD TV and plasma TV; however, these have adversely affected the cinema theaters. The fast changes in technologies also create problems for enterprises as they render plants and products obsolete quickly. Product-market-technology matrix generally has a much shorter life today than in the past (Feenstra and Hanson 2005).

\section{Market and sales forecasting in international environment}

Market and sales forecasting are fundamental to the theory and practice of international marketing activities (Feenstra and Hanson 2005). Without a sales forecast, in the short term, operations can only respond retroactively, leading to lost orders, inadequate service, and poorly utilized production resources. In the longer term, financial and market decision-making misallocate resources so that the organization's continuing existence may be brought into question. With such consequences, it is hardly surprising that the management science literature has long been filled with attempts to improve the quality of an organization's market forecasts. In surveys of management science/operational research practice, forecasting is placed at the head of the techniques employed. Allen (2003) argued that the years since 1960 have witnessed major growth in research into forecasting. However, most of that research and almost all of 
the textbooks have concentrated on only one aspect of the problem: how to develop appropriate forecasting methods. In parallel with the technical research into forecasting methods, some researchers have examined market forecasting practices. They have been concerned with such factors as the level of aggregation for which a forecast is made (from product up to industry), the time horizon of the forecast, the methods used, and the accuracy achieved. In any organization, the objectives of the market forecasting process are not straightforward, and different organizational objectives will be better served by a matching organizational design. While these objectives will usually, if not invariably, include statistical notions such as accuracy and bias, more general aspects of the marketing function are also affected such as improved competitive intelligence and sales force motivation. The relative importance (both perceived and actual) of any particular objective will vary from organization to organization. The term "environmental uncertainty" is used loosely by various authors but includes market uncertainty. Barringer and Ireland (2005) examined the linkage between external forecasting services and decision makers within organizations, contrasting a normative view of what should happen with empirical evidence. Makridakis et al. (1983) are the only authors to examine all aspects of the problem. These various studies identified the following factors as potentially important in understanding the effectiveness of an organization in responding to its market uncertainty:

- The link between the forecast and the decision, and the corresponding interaction between the forecaster and the decision maker, and their personality traits;

- Information flows both between the environment and the organization and within the organization itself; and

- The technical characteristics of the forecast (e.g., accuracy).

Summarily, the credibility and impact of the forecast will depend on such features as the personal characteristics of forecaster and decision maker and their motivation, the links between the forecasters and the user, the overall importance of uncertainty in the planning process, and the organization's dependence on the forecast numbers and associated uncertainty.

\section{Domestic markets and international competitiveness}

Firms are operating in an economy that is becoming increasingly global. The worldwide reduction of trade and investment barriers through the World Trade Organization and the establishment of regional economic cooperation agreements such as the European Union have diminished barriers for SMEs and new ventures to become internationally active. Also, technological advancements (including the widespread use of Internet and e-mail) and falling transportation costs have resulted in enhanced information flows between countries which facilitate small and new venture internationalization (Autio 2005; Reynolds 1997a. It has, for example, become easier for small and new ventures to find information about foreign markets and about clients abroad, to communicate with foreign partners, and to coordinate various activities across borders. An increasingly global economy presents firms with both opportunities and threats (Greenaway et al. 2008). Substantial opportunities arise for small and new ventures, such as to expand 
sales or business activities abroad, to target specific international niches, or to access advanced technologies abroad. According to Feenstra and Hanson 2005, "Buy low, sell high" logic leads economists to comparative advantage theory. Comparative advantage means the comparison of relative price differences between nations to explain the pattern of trade. Entrepreneurship, as measured by various indicators such as start-up activity rates or the increase in business ownership, plays an important role in national economies (van Stel 2006). Entrepreneurship is considered to be an important mechanism for national economic development, e.g., through its contribution to the generation of employment and innovation (Acs and Audretsch 2003; Autio 1994; Baumol 2002; Carree and Thurik 2003; Wennekers and Thurik 1999; Schumpeter, 1934). However, considerable differences exist between countries in the extent to which entrepreneurship contributes positively to national economic development. To gain insight into the factors that affect the emergence of entrepreneurship and into the economic outcomes of various types of entrepreneurship, the significance of entrepreneurship for national economies is important in considering cross-border entrepreneurship or the involvement of SMEs and new ventures in the international economy despite environmental forces that limits firms' performance outside their regions of operation. Cross-border activities, such as exports, are an important means through which small and new ventures are able to create value, to generate growth, and to access new knowledge and technologies abroad (Yeoh 2004). Nowadays, the internationalization of SMEs and new ventures is both expanding and accelerating, which is likely to further contribute to a greater number of economic actors pursuing foreign markets (Hessels 2007). The expansion and acceleration of cross-border entrepreneurship should be considered in the light of substantial changes that took place in the past decades and that resulted in a reduction of transaction costs for undertaking international business. Threats may result from increased foreign competition (Acs et al. 2003), which may provide a greater necessity for small and new firms to look beyond national borders to survive or grow in complex business environment depending on the entrepreneur drive of the business owners (McDougall and Oviatt 2000; Root 1994).

\section{Method}

This paper being descriptive and historical relied heavily on secondary sources of information. The descriptive and historical method has been resulted to because (cited in Gill and Johnson 1991, 2010) observes that descriptive and historical methods were beneficial because the historical point of view which is the point of view of change will enhance the understanding and extend the horizon. It will be difficult to find a more confident and clearer statement in support of descriptive and historical methodology than this. This is because Hopf's (1944) statement was based on the belief that the changing events and developments of the past provided understanding of the dynamics of ordered human enterprise (Creswell 2013). This type of methodology was regarded as one that does not fit into either quantitative or qualitative research method (Yin 2011). It utilizes elements of both within the same study. This type of research methodology can also employ multiple variables for analysis (if needed); on the other hand, it is unlike other methodology in that it requires only one variable, and in the present study, the variable is international marketing environmental challenges. However, Yin (2011) stressed that the four main purposes of secondary sources methodology are to 
describe, to explain, to validate findings, and to infer from all the findings having been validated in this study.

\section{Summary, conclusion, and recommendations Summary and conclusion}

The importance of international marketing environment in today's global world cannot be over-emphasized. International entrepreneurs all over the world go as far as possible to transact businesses out of their local regions to earn revenue and boost profitability cum acceptability of their products in the global markets. This study among others found that while there are so many hurdles to contend with in the international arena by entrepreneurs, potential opportunities exist and can be effectively harnessed. Furthermore, the analyses of the PESTEL factors showcase varying degrees of issues entrepreneurs must contend with in order to make headways in their drive for a profitable venture. Technology has become a very important factor in most businesses, and it was established that advancement in global technologies does affect most entrepreneurial profitability positively, though not all entrepreneurs have adopted the usage of technological products to transact their businesses. Most entrepreneurs only have technological interactions during the period of banking transactions to settle for commodities. The analyses further revealed that detailed awareness of cultural environments can enhance the business dealings of entrepreneurs in a foreign country. In essence an entrepreneur that does not understand the culture of the country where the business is being transacted may come out with losses, for example, language could be a barrier and lack of understanding of values of the host countries of dealings may be a hindrance. This is because things that are applicable to cultural values in one economy may not be applicable in others. Another very critical issue is government regulation and environmental challenge; these have a lot to do with international transactions and earnings of entrepreneurs. Entrepreneurs must consider government regulations that are prevalent in the country of operations so as to understand their limits for any dealings they want to engage in. Finally, the ability of an entrepreneur to make substantial profit from international dealings is dependent on the potential to align the business with all the above listed.

\section{Recommendations}

Based on the findings of the study, the following are the recommendations:

- Since it has been reflected in this study that technological products have not really provided enough benefits for international entrepreneurs as expected, organizations should endeavor to provide indispensable technologies that support international transactions.

- International products should be regulated and controlled efficiently in terms of pricing and service quality based on the findings which showed that they have tendency to produce below standards without government regulations.

- The cultural factors in countries of dealings should be considered as a very serious element of international business success. 
- Government should invest more into infrastructures by providing enabling environments so that there will be more international entrepreneurs and these will create more jobs and reduce unemployment.

\section{Limitations and suggestions for future line of studies}

This study is limited in scope as the coverage is within entrepreneurial ventures into international markets and the challenges they face. With this study serving as a foundation, future studies can dwell on the role of government in promoting international businesses. Furthermore, this study adopted the secondary research methods; future studies can utilize the quantitative, qualitative, or mixed methods to advance the frontiers of knowledge.

\section{Authors' contributions}

Both authors read and approved the final manuscript.

\section{Competing interests}

The authors declare that they have no competing interests.

\section{Publisher's Note}

Springer Nature remains neutral with regard to jurisdictional claims in published maps and institutional affiliations.

Received: 9 October 2017 Accepted: 5 September 2018

Published online: 26 September 2018

\section{References}

Acs, Z. J., \& Audretsch, D. B. (2003). In Z. J. Acs \& D. B. Audretsch (Eds.), Innovation and technological change.

Acs, Z. J., Dana, L.P., \& Jones, M. V. (2003). Toward new horizons: the internationalization of entrepreneurship. Journal of International Entrepreneurship, 1(1), 5-12.

Agwu, M. E. (2018). Relevance of information technology in the effective management of selected SMEs in Lagos State Nigeria. Academy of Strategic Management Journal 1939-6104-17-1-174, Volume 17, Issue 1, 2018, pp.1-15; Available at: https:/www.abacademies.org/journals/academy-of-strategic-management-journal-current-issue.html.

Agwu, M. E., Onwuegbuzie, H. N., \& Ezeifeka, P. (2017). Impact of entrepreneurship education on new ventures creation - a case study. Advances in Social Sci Res J, (425), 98-114 Available at: http://scholarpublishing.org/index.php/ASSRJ/article/ view/4014.

Allen, K. (2003). Launching new ventures: an entrepreneurial approach (3rd ed.). Boston: Houghton Mifflin.

Autio, E. (1994). New technology-based firms as agents of R\&D and innovation. Technovation, 14(4), 259-273.

Autio, E. (2005). Creative tension: the significance of ben Oviatt's and Patricia McDougall's article 'Toward a theory of international new Ventures'. Journal of International Business Studies, 36(1), 9-19.

Ayoade, O. E., \& Agwu, M. E. (2016). Employment generation through entrepreneurial development: the Nigerian experience. British Journal of Economics, Management \& Trade, 11(3), 1-14.

Barringer, B., \& Ireland, D. (2005). Entrepreneurship: successfully launching new ventures. Boston, NJ: Pearson Education.

Baumol, W. J. (2002). The free-market innovation machine: analyzing the growth miracle of capitalism. Princeton: Princeton University Press.

Biraglia, A., \& Kadile, V. (2017). The role of entrepreneurial passion and creativity in developing entrepreneurial intentions: insights from American home brewers. Journal of Small Business Management, 55(1), 170-188.

Cardon, M. S., \& Kirk, C. P. (2015). Entrepreneurial passion as mediator of the self-efficacy to persistence relationship. Entrepreneurship: Theory and Practice, 39(5), 1027-1050.

Carree, M. A., \& Thurik, A. R. (2003). The impact of entrepreneurship on economic growth. In Z. J. Acs \& D. B. Audretsch (Eds.), Handbook of entrepreneurship research (pp. 437-471). Boston: Kluwer Academic Publishers.

Coulter, R. A., Strizhakova, Y., \& Price, L. L. (2008). Branded products as a passport to global citizenship: perspectives from developed and developing countries. Journal of International Marketing, 16(4), 57-85.

Creswell, J. W. (2013). Research design: qualitative, quantitative, and mixed methods approaches. Thousand Oaks, CA: Sage Publications.

Davis, B. C., Hmieleski, K. M., Webb, J. W., \& Coombs, J. E. (2017). Funders' positive affective reactions to entrepreneurs' crowdfunding pitches: the influence of perceived product creativity and entrepreneurial passion. Journal of Business Venturing, 32(1), 90-106.

Feenstra, R., \& Hanson, G. (2005). Ownership and control in outsourcing to China: estimating the property-rights theory of the firm. Quarterly Journal of Economics, 120(2), 729-761 May.

Gill, J., \& Johnson, P. (1991). Research Methods for Managers (4th ed.). London: Paul Chapman.

Gill, J., \& Johnson, P. (2010). Research methods for managers (4th ed.). London: Paul Chapman Ltd.

Greenaway, D., Gullstrand, J., \& Kneller, R. (2008). Surviving globalisation. Journal of International Economics, 74(2), 264-277.

Hamel, G., \& Prahalad, C. (1994). Competing for the future. Boston: Harvard Business School Press.

Hessels, J. (2007). Reactie op: Kentering in het Denken over Mondiale Strategieën (Response to: A Shift in Thinking about Global Strategies). ESB dossier Globaliseren in Nederland, 92, 59. 
Johanson, J., \& Vahlne, J.-E. (1977). The internationalization process of the firm: a model of knowledge development and increasing foreign market commitments. Journal of International Business Studies, 8(1), 23-32.

Johanson, J., \& Vahlne, J.-E. (1990). The mechanism of internationalization. International Marketing Review, 7(4), 11-24. Kotler, P. (2007). Marketing management (pp. 88-92). (Nineth Edition) Prentice Hall, New Jersey 103.

Lim, D. S. K., Oh, C. H., \& Clercq, D. D. (2016). Engagement in entrepreneurship in emerging economies: interactive effects of individual-level factors and institutional conditions. International Business Review, 25(4), 933-945.

Mahmoud, M. A., \& Muharam, F. M. (2014). Factors Affecting the Entrepreneurial Intention of PhD Candidates: A study of Nigerian International Students of UUM. European Journal of Business and Management, 6(36), 17-24.

Makridakis, S., Wheelwright, S. C., \& McGEE, V. E. (1983). Forecasting: methods and applications (2nd ed.). New York: Wiley.

McDougall, P. P., \& Oviatt, B. M. (2000). International entrepreneurship: the intersection of two research paths. Academy of Management Journal, 43(5), 902-906.

Muller, A. (2004). The rise of regionalism. Rotterdam: ERIM PhD Series.

Murnieks, C. Y., Cardon, M. S., Sudek, R., White, T. D., \& Brooks, W. T. (2016). Drawn to the fire: the role of passion, tenacity and inspirational leadership in angel investing. Journal of Business Venturing, 31(4), 468-484.

OECD. (1997). Globalization and small and medium enterprises (Vol. 1). Paris: OECD.

Onwuegbuzie, H. N., \& Agwu, M. E. (2018) Changing the present and creating the future through indigenous knowledge and entrepreneurship. Academy of Entrepreneurship Journal, 24, Issue 1, pp. 1-15. 1528-2686-24-1-121 Volume 2018. https:// www.abacademies.org/journals/academy-of-entrepreneurship-journal-current-issue.html .

Prahalad, C.K., \& Mashelkar, R.A. (2010). Innovation's holy grail. Harvard Business Review 88(7/8), pp. $132-141$.

Rennie, M. W. (1993). Global competitiveness: born global. The McKinsey Quarterly, 4, 45-52.

Reynolds, P.D. 1997a. New and small firms in expanding markets, Small Business Economics, 9(1), 78-84.

Root, F. (1994). Entry strategies for international markets. Lexington, MA: Lexington Books.

Schumpeter, J.A. (1934). The Theory of Economic Development: An inquiry into profits, capital, credit, interest and the business cycle. Transaction Publishers. New Jersey.

Shane, S. (2003). A general theory of entrepreneurship: the individual opportunity nexus. Northhampton, MA: Edward Elgar.

Stel, A.J. van. (2006). Empirical Analysis of Entrepreneurship and Economic Growth (International Studies in Entrepreneurship series, Vol. 13), New York: Springer Science.

Stephan, U., \& Stride, C. (2015). Institutions and social entrepreneurship: the role of institutional voids, institutional support, and institutional configurations. Journal of International Business Studies, 46, 308-331.

Taiwo, J. N., \& Agwu, M. E. (2016). Problems and prospects of Poverty Alleviation Programmes in Nigeria. International Journal of Business and Management Review, 4(6), 18-30 August 2016.

Taiwo, J. N., Agwu, M. E., Adetiloye, K. A., \& Afolabi, G. T. (2016). Financing women entrepreneurs and employment generation - a case study of microfinance banks. European Journal of Social Sciences, 52(1), 112-126 May, 2016, pp.

Tallman, S., \& Li, J. T. (1996). Effects of international diversity and product diversity on the performance of multinational firms. Academy of Management Journal, 39, 179-196.

Van der Zwan, P., Thurik, A. R., \& Grilo, I. (2010). The entrepreneurial ladder and its determinants. Appl Econ, 42(17), $2183-2191$.

Wennekers, A. R. M., \& Thurik, A. R. (1999). Linking entrepreneurship and economic growth. Small Business Economics, 13(1), 27-55.

Yeoh, P.-L. (2004). International learning: antecedents and performance implications among newly internationalizing companies in an exporting context. International Marketing Review, 21(4-5), 511-535.

Yin, R. K. (2011). Qualitative research from start to finish. New York: Guilford.

Zwan, P., Thurik, R., Verheul, I., \& Hessels, J. (2016). Factors influencing the entrepreneurial engagement of opportunity and necessity entrepreneurs. Eurasian Business Review, 6(3), 273-295.

\section{Submit your manuscript to a SpringerOpen ${ }^{\circ}$ journal and benefit from:}

- Convenient online submission

- Rigorous peer review

- Open access: articles freely available online

- High visibility within the field

- Retaining the copyright to your article

Submit your next manuscript at $\mathbf{s p r i n g e r o p e n . c o m ~}$ 